\title{
MộT SỐ NHẬN XÉT VỀ KỸ THUẬT VÀ KẾT QUẢ BƯớC ĐẦU PHẪU THUẬT NộI SOI LỒNG NGỰC CẮT THÙY PHỔI TẠI BỆNH VIỆN QUÂN Y 103
}

\begin{abstract}
Vũ Anh Hải*, Nguyễn Văn Nam*, Nguyễn Ngọc Trung*, Lê Việt Anh*, Trần Thanh Bình*, Lại Hợp Hậu*, Nguyễn Khánh*, Phan Duy Nguyên*, Đặng Tuấn Nghĩa*, Nguyễn Trường Giang*
\end{abstract}

\section{TÓM TẮT}

31 bệnh nhân được PTNS cắt thùy phổi từ $5 / 2016$ đến $9 / 2017$. Nghiên cứu mô tả, tiến cứu, không đối chứng. PTNS được chỉ định để cắt tất cả các vị trí thùy phổi, gồm bệnh phổi lành tính (tỷ lệ 16\%) và ung thư phổi (84\%). Cả 02 phương pháp PTNS được áp dụng (PTNS hoàn toàn 64,6\%; PTNS hỗ trợ 35,4\%), PTNS hỗ trợ thường được áp dụng ở những trường hợp u phổi có kích thước lớn trên $5 \mathrm{~cm}$, rãnh liên thùy không hoàn toàn $(\mathrm{p}<0,05)$. Tĩnh mạch luôn được cắt đầu tiên khi cắt thùy trên phổi (14/14 trường hợp), phế quản luôn được cắt sau khi cắt các mạch máu (tỷ lệ $100 \%)$. PTNS vét hạch ở bệnh nhân ung thư phổi hiệu quả với $58,3 \%$ vét được hạch $\mathrm{N} 1$, 69,4\% vét hạch N2, số vị trí vét được hạch trung bình là $1,6 \pm 1,0$. Kết quả phẫu thuật khả quan với tỷ lệ tai biến và biến chứng thấp $(6,4 \%)$. Không có tử vong trong và sau mố.

* Tù khóa: Phẫu thuật nội soi lồng ngục, Phẫu thuật nội soi cắt thùy phổi

\section{ABSTRACT \\ THORACOSCOPIC LOBECTOMY IN \\ MILITARY HOSPITAL 103: TECHNIQUE AND INITIAL RESULTS}

31 patients underwent operation by thoracoscopic surgery lobectomy at the Military hospital 103 from 05/2016 to 9/2017. Methods: prospective, descriptive. Thoracoscopic lobectomy was indicated for all lung segments that include benign lung disease (16\%) and lung cancer $(84 \%)$. The operation procedures included: thoracoscopic surgery (64.6\%) and video-assisted thoracoscopic surgery (VATS) (35.4\%), VATS was indicated in patient with tumor's size $>5 \mathrm{~cm}$, the fissure was not clear $(\mathrm{p}<0.05)$. The pulmonary vein was always cut first with upper lobar (14/14 of patients), the bronchus was divided after excision of pulmonary vein and artery $(100 \%)$. The lympho nodes excision in lung cancer included: N1 (58.3\%), N2 (69.4\%), the average number of lympho nodes resection was $1.6 \pm 1$. Results: low rate of complication (6.4\%). The death rate in and post - operative was $0 \%$.

*Keywords: thoracoscopic surgery, VATS lobectomy

\section{I. ĐẶT VẤN ĐỀ}

Nội soi lồng ngực được thực hiện đầu tiên bởi Jacobaeus năm 1910 tại bệnh viện Serafimerla sarettet ở Stockholm. Đến năm 1992, cắt thùy phổi bằng phẫu thuật nội soi lồng ngực lần đầu tiên được thực hiện thành công [1], [7], [9].

Ngày nay, nhiều trung tâm trên thế giới đã áp dụng kỹ thuật này. Tại Việt Nam, phẫu thuật nội soi lồng ngực được đưa vào áp dụng từ năm 1996. Tuy nhiên, kỹ thuật phẫu thuật chưa được thống nhất, vấn đề chỉ định áp dụng cũng còn nhiều tranh luận, nhất là trong phẫu thuật cắt thùy phổi điều trị ung thư phổi [2], [8], [10].

Xuất phát từ thực tiễn trên, chúng tôi thực hiện nghiên cứu nhằm mục tiêu: Nhận xét kỹy thuật và đánh giá kết quả buoớc đầu phẫu thuật

\footnotetext{
* Bệnh viện Quân y 103 - Học viện Quân y Ngưòi chịu trách nhiệm khoa học: PGS.TS. Nguyễn Truòng Giang Ngày nhận bài: 01/05/2018 - Ngày Cho Phép Đăng: 20/05/2018 Phản Biện Khoa học: PGS.TS. Đạng Ngọc Hùng GS.TS. Lê Ngọc Thành
} 
nội soi lồng ngục cắt thùy phổi tại Bệnh viện Quân y 103

\section{II. ĐỐI TƯợNG VÀ PHƯƠNG PHÁP}

\section{1. Đối tượng nghiên cứu}

31 bệnh nhân được chỉ định phẫu thuật nội soi cắt thùy phổi tại khoa Phẫu thuật lồng ngực Tim mạch, Bệnh viện Quân y 103 từ 5/2016 đến 9/2017.

\subsection{Phương pháp nghiên cứu}

Nghiên cứu tiến cứu, mô tả, không đối chứng.

2.3. Quy trình phẫu thuật và chăm sóc sau mố

- Chỉ định phẫu thuật nội soi cắt thùy phổi

+ Bệnh nhân đủ điều kiện để phẫu thuật lồng ngực, chịu đựng được gây mê một phổi, không có bệnh lý màng phổi và phẫu thuật khoang màng phổi trước đó.

+ Bệnh phổi lành tính: dãn phế quản khu trú; u phổi lành tính nhưng vị trí u nằm sâu trong nhu mô phổi hay u kích thước lớn không thể cắt phổi hình chêm; phổi biệt lập ...

+ Ung thư phổi nguyên phát: giai đoạn I, II, $\mathrm{u}$ kích thước $<6 \mathrm{~cm}$.

\section{- Quy trình kỹ thuật phẫu thuật nội soi cắt thùy phổi}

+ Vô cảm: thông khí chọn lọc một phổi bằng ống nội khí quản hai nòng.

+ Tư thế bệnh nhân: Nằm nghiêng 90 độ, độn gối dưới bờ sườn.

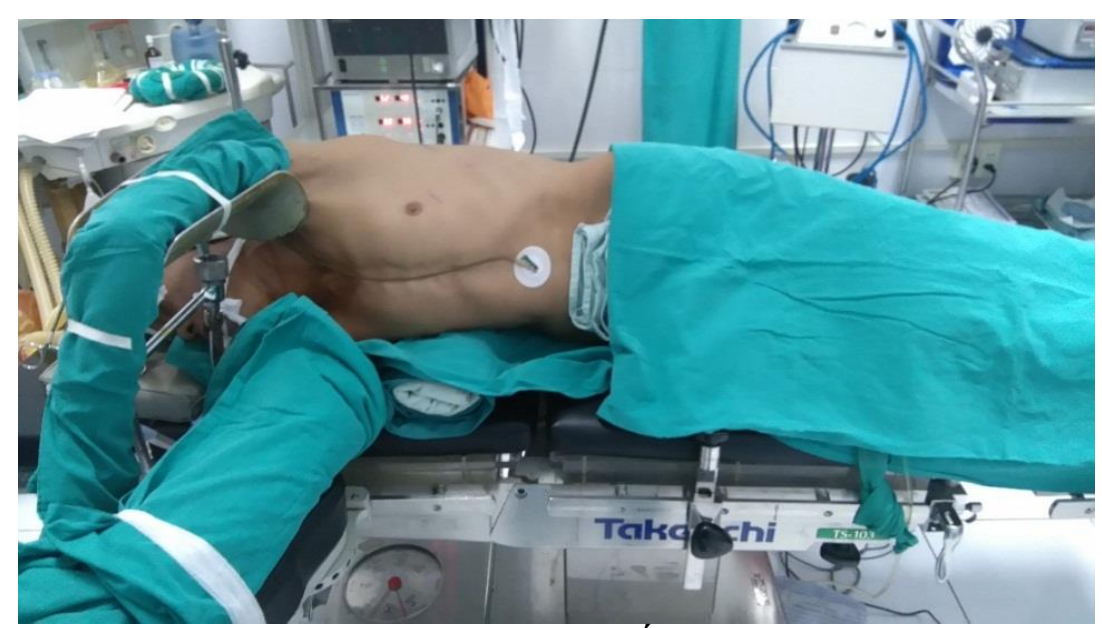

Hình 1. Tu thế bệnh nhân

+ Vị trí kíp phẫu thuật:

- Phẫu thuật viên chính: luôn đứng bên phải bệnh nhân

• Phẫu thuật viên phụ 1: đối diện phẫu thuật viên chính

- Phẫu thuật viên phụ 2: cùng bên phẫu thuật viên chính

• Kỹ thuật viên dụng cụ: bên trái phẫu thuật viên phụ 1

+ Màn hình máy nội soi: 2 màn hình nội soi ở hai bên bàn mổ để cho phẫu thuật viên chính và phẫu thuật viên phụ 1 quan sát, góc khoảng 15 - 30 độ.
+ Các bước kỹ thuật:

Bước 1: Đặt trocar

Trocar $10 \mathrm{~mm}$ cho ống soi, thường được đặt tại khoang liên sườn VII hoặc VIII đường nách giữa.

Trocar 12mm ở khoang liên sườn 6 hoặc 7 đường nách sau để đưa dụng cụ vén phổi.

Bước 2: Đánh giá tổn thương và quyết định phương pháp phẫu thuật

Đánh giá tình trạng dầy dính khoang màng phổi (KMP): Có dày dính hay không (phổi tự do hoàn toàn) 
Tình trạng rãnh liên thùy : Hoàn toàn hay không hoàn toàn

Xác định vị trí, kích thước và tính chất tổn thương (xâm lấn tại mạch máu, thùy phổi liền kề, màng phổi hay không)

Quyết định phương pháp phẫu thuật:

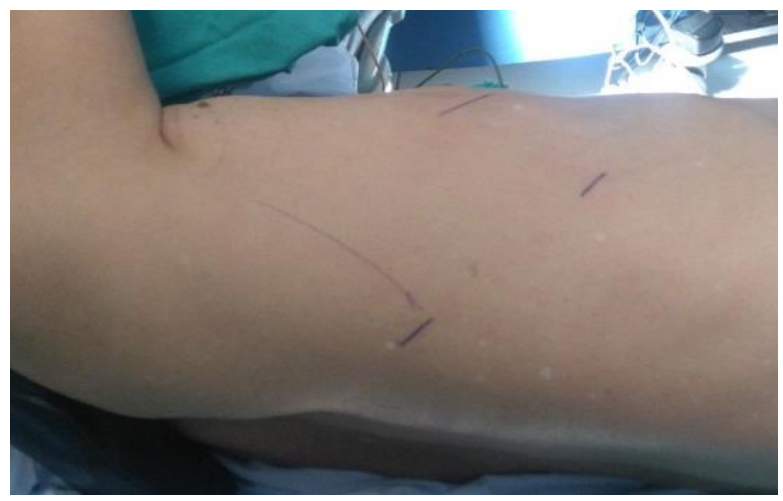

Hình 2. Vị trí đặt trocar và đưòng mở ngục

- PTNS hỗ trợ: Mở ngực 8 - 10cm, vị trí KLS IV hoặc $\mathrm{V}$, đường nách trước. Sử dụng banh sườn nhỏ để mở rộng KSL để có thể đưa các dụng cụ mổ mở có cán dài qua vị trí này (thường $3 \mathrm{~cm}$ )

Bước 3: Cắt thùy phổi và vét hạch

Các thành phần cuống thùy phổi được phẫu tích và cắt riêng theo giải phẫu. Sử dụng dụng cụ khâu cắt nội soi để cắt mạch máu phổi, phế quản và rãnh liên thùy. Với các nhánh nhỏ động mạch có thể sử dụng hemolock

Đặt ống dẫn lưu khoang màng phổi.
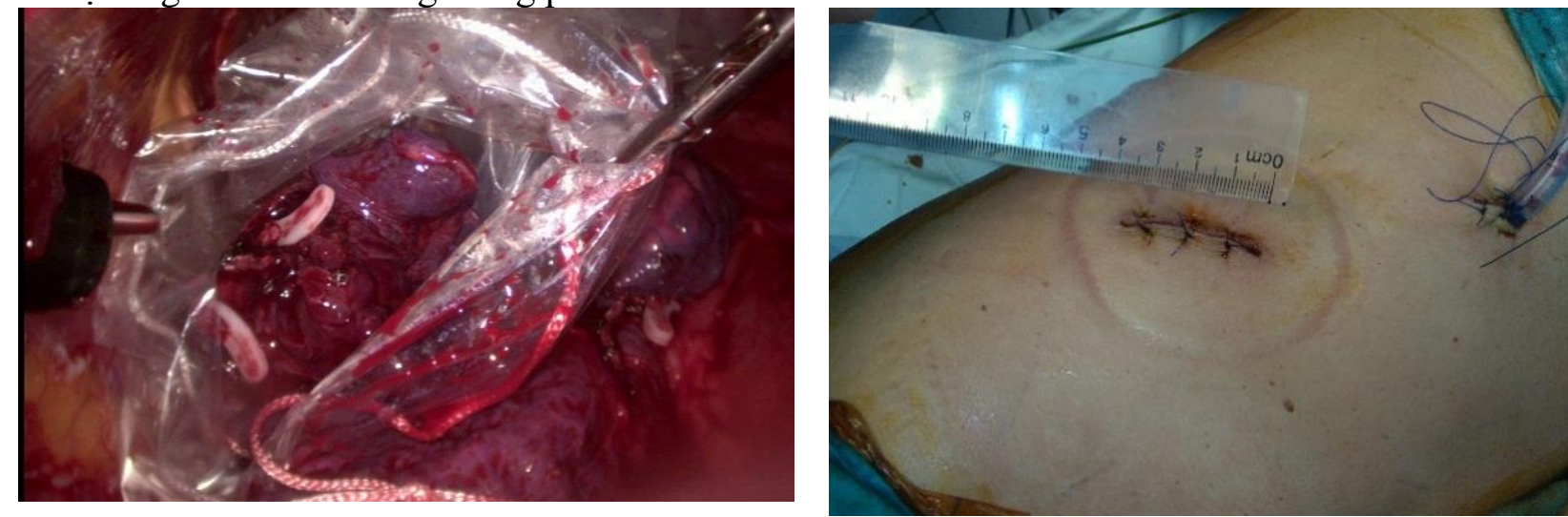

Hình 3. Kết thúc phẫu thuật
- PTNS hoàn toàn: Mở ngực nhỏ khoảng 3 - $5 \mathrm{~cm}$ tại khoang liên sườn 4 hoặc 5 đường nách trước. Không dùng dụng cụ banh sườn, mà sử dụng Wound retractor/protector bằng silicon để banh cơ và cô lập đường mổ.

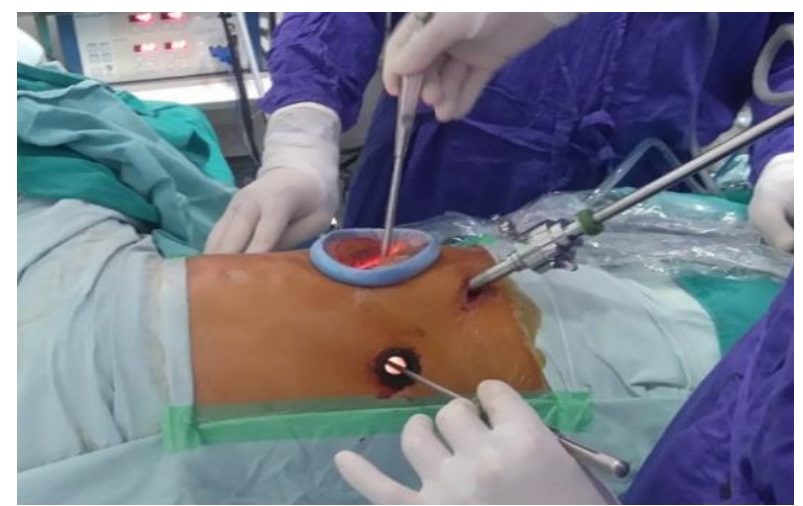

Tiến hành vét hạch theo hệ thống nếu kết quả tế bào/ mô bệnh của khổi u là ung thư (dựa trên kết quả sinh thiết trước mổ hoặc mô học tức thì trong mổ).

Bước 4: Kết thúc phẫu thuật

Bệnh phẩm được cho vào túi, lấy ra khỏi lồng ngực.

Kiểm tra cầm máu. Rửa sạch khoang màng phổi, đánh giá tình trạng nở phổi, kiểm tra các vị trí dò khí để khâu tăng cường. 


\subsection{Các chỉ tiêu nghiên cứu}

2.4.1. Đặc điểm chung

Tuổi, giới tính

2.4.2. Quy trình phẫu thuật

a. Chi dinh

- Theo vị trí thùy phổi được cắt

- Kích thước khối u (đường kính lớn nhất của khối u đo được sau khi cắt thùy phổi)

- Bệnh lý phẫu thuật (theo kết quả mô bệnh học sau mổ)

- Giai đoạn TNM trước phẫu thuật theo AJCC 2009 (với những trường hợp ung thư phổi không tế bào nhỏ)

- Đặc điểm tổn thương đánh giá được khi đưa ống soi quan sát: Mức độ dầy dính KMP; tính chất xâm lấn của tổn thương; đặc điểm rãnh liên thùy.

b. Kỹ thuật phẫu thuật

- Phương pháp PTNS: Hoàn toàn hay hỗ trợ
PTNS hoàn toàn: Mở ngực nhỏ (3 - 5cm), sử dụng dụng cụ PTNS lồng ngực chuyên dụng, quá trình phẫu thuật quan sát toàn bộ trên màn hình nội soi

PTNS hỗ trợ: Mở ngực $8-10 \mathrm{~cm}$, sử dụng kết hợp các dụng cụ mổ mở có cán dài, quá trình phẫu thuật kết hợp quan sát trực tiếp và màn hình nội soi

- Trình tự xử lý các thành phần cuống thùy

- Vét hạch (với những trường hợp UTP không TBN)

2.4.3. Đánh giá kết quả

- Thời gian, máu mất trong mổ

- Thời gian dẫn lưu KMP, nằm viện sau mổ

- Biến chứng trong và sau mổ

- Tử vong phẫu thuật (tháng đầu tiên sau mổ).

\subsection{Xử lý số liệu}

Xử lý số liệu bằng phần mềm thống kê Epi Info 3.3.2.

\section{KẾT QUẢ}

Trong thời gian nghiên cứu, có 31 bệnh nhân đủ tiêu chuẩn chọn bệnh, với:

- Tuổi trung bình là 57,0 $\pm 8,4$ (nhỏ nhất 40, lớn nhất 72)

- Nam giới 25 trường hợp (chiếm 80,6\%) và nữ 6 trường hợp (tỷ lệ 19,4\%)

\section{1. Đặc điểm kỹ thuật}

\subsubsection{Chỉ định}

Bảng 3.1. Vị trí thùy phổi đưọ̣c cắt

\begin{tabular}{|l|c|c|}
\hline \multicolumn{1}{|c|}{ Vị trí u phổi } & Số bệnh nhân & Tỷ lệ (\%) \\
\hline Thùy trên phổi P & 6 & 19,3 \\
\hline Thùy giữa phổi P & 1 & 3,2 \\
\hline Thùy dưới phổi P & 11 & 35,4 \\
\hline Thùy trên phổi T & 8 & 25,8 \\
\hline Thùy dưới phổi T & 5 & 16,3 \\
\hline \multicolumn{1}{c|}{ Tổng } & 31 & 100 \\
\hline
\end{tabular}

Nhận xét: Tất cả các thùy phổi đều có thể cắt bằng PTNS. Phổi phải chiếm ưu thế hơn $(18 / 31=58,1 \%)$.

Bảng 3.2. Kích thước tổn thương

\begin{tabular}{|c|c|c|c|}
\hline & Nhỏ nhất & Lớn nhất & Trung bình \\
\hline Kích thước tổn thương (cm) & 1,2 & 7,5 & $3,3 \pm 1,4$ \\
\hline
\end{tabular}

Nhận xét: PTNS cắt thùy phổi có thể thực hiện khi kích thước khối u lớn nhất đến $7,5 \mathrm{~cm}$. 
Bảng 3.3. Bệnh lý phổi được điều trị bằng phẫu thuật nội soi cắt thùy

\begin{tabular}{|l|c|c|}
\hline \multicolumn{1}{|c|}{ Bệnh lý phổi } & Số bệnh nhân & Tỷ lệ (\%) \\
\hline Ung thư không tế bào nhỏ & 26 & 84,0 \\
\hline U mạch & 1 & 3,2 \\
\hline U lao & 2 & 6,4 \\
\hline Hamartoma & 1 & 3,2 \\
\hline Áp xe phổi Tổng & 1 & 3,2 \\
\hline \multicolumn{2}{|c|}{ Tồn } & 100,0
\end{tabular}

Nhận xét: Ung thư phổi không tế bào nhỏ là bệnh lý chiếm chủ yếu được chỉ định PTNS cắt thùy phổi điều trị (tỷ lệ 84,0\%).

Bảng 3.4. Đặc điểm rãnh liên thùy và dầy dính khoang màng phổi

\begin{tabular}{|l|c|c|c|}
\hline \multicolumn{2}{|c|}{ Chỉ tiêu } & Số bệnh nhân & Tỷ lệ (\%) \\
\hline \multirow{2}{*}{ Dầy dính KMP } & Có & 14 & 45,2 \\
\cline { 2 - 4 } & Không & 17 & 54,8 \\
\hline \multirow{2}{*}{ Rãnh liên thùy } & Hoàn toàn & 17 & 54,8 \\
\cline { 2 - 4 } & Không hoàn toàn & 14 & 45,2
\end{tabular}

Nhận xét: PTNS cắt thùy phổi ở cả những $\mathrm{BN}$ có rãnh liên thùy không hoàn toàn (tỷ lệ $45,2 \%$ ) và có dày dính $\mathrm{KMP}(45,2 \%)$.

Bảng 3.5. Giai đoạn TNM trước mổ $(\mathrm{n}=26)$

\begin{tabular}{|c|c|c|}
\hline Giai đoạn TNM & Số bệnh nhân & Tỷ lệ (\%) \\
\hline IA & 11 & 42,3 \\
\hline IB & 11 & 42,3 \\
\hline IIA & 1 & 3,8 \\
\hline IIB & 1 & 3,8 \\
\hline IIIA & 2 & 7,7 \\
\hline
\end{tabular}

Nhận xét: BN ung thư phổi không tế bào nhỏ giai đoạn I chiếm chủ yếu $(84,6 \%)$.

\subsubsection{Kỹ thuật phẫu thuật}

Trong số 31 bệnh nhân, chúng tôi thực hiện PTNS hoàn toàn cắt thùy phổi cho 20 trường hợp (chiếm 64,5\%), 11 trường hợp được PTNS hỗ trợ (tỷ lệ 35,5\%).

Bảng 3.6. Liên quan phương pháp phẫu thuật nội soi và một số yếu tố

\begin{tabular}{|c|c|c|c|c|}
\hline \multicolumn{2}{|c|}{ Chỉ tiêu } & Nội soi hoàn toàn & Nội soi hỗ trọ & $\mathbf{P}$ \\
\hline \multirow{2}{*}{ Dày dính KMP } & Có & 8 & 6 & \multirow{2}{*}{$>0,05^{\mathrm{a}}$} \\
\hline & Không & 12 & 5 & \\
\hline \multirow{2}{*}{ Rãnh liên thùy } & Có & 15 & 2 & \multirow{2}{*}{$0,007^{b}$} \\
\hline & Không & 5 & 9 & \\
\hline \multirow{2}{*}{$\begin{array}{l}\text { U dính màng phổi } \\
\text { thành }\end{array}$} & Có & 1 & 2 & \multirow{2}{*}{$>0,05^{b}$} \\
\hline & Không & 19 & 9 & \\
\hline \multirow{2}{*}{ Kích thước u } & $\geq 5 \mathrm{~cm}$ & 0 & 4 & \multirow{2}{*}{$\mathbf{0 , 0 1}{ }^{b}$} \\
\hline & $<5 \mathrm{~cm}$ & 20 & 7 & \\
\hline \multirow{2}{*}{ Mô bệnh học } & UTP & 18 & 9 & \multirow{2}{*}{$>0,05^{\mathrm{b}}$} \\
\hline & U lành & 2 & 2 & \\
\hline
\end{tabular}

Nhận xét: Rãnh liên thùy không hoàn toàn, kích thước $\mathrm{u}$ từ $5 \mathrm{~cm}$ trở lên là yếu tố có chi phối tới quyết định lựa chọn phương pháp PTNS hỗ trợ. 
Bảng 3.7. Thành phần cuống thùy được cắt trước theo thùy phổi

\begin{tabular}{|l|c|c|c|}
\hline \multirow{2}{*}{$\begin{array}{c}\text { Thành phần cuống thùy } \\
\text { được cắt cắt trước }\end{array}$} & Trên & Giữa & Dưới \\
\cline { 2 - 4 } & 0 & 0 & 7 \\
\hline Động mạch phổi & 14 & 1 & 9 \\
\hline Tĩnh mạch phổi & \multicolumn{3}{|c|}{} \\
\hline Phế quản & \multicolumn{3}{|c|}{0} \\
\hline
\end{tabular}

Nhận xét: Khi cắt thùy trên, TM luôn được cắt trước (14/14 bệnh nhân). ĐM phổi được cắt trước khi cắt thùy dưới phổi chiếm tỷ lệ 43,8\% (7/16 trường hợp).

Bảng 3.8. Nhóm hạch được vét trong mổ

\begin{tabular}{|l|c|c|}
\hline \multicolumn{1}{|c|}{ Nhóm hạch } & Số bệnh nhân & Tỷ lệ (\%) \\
\hline Hạch trong và rốn phổi (N1) & 21 & 58,3 \\
\hline Hạch trung thất (N2) & 25 & 69,4 \\
\hline Số hạch trung bình được vét & \multicolumn{2}{|c|}{$1,6 \pm 1,0$}
\end{tabular}

Nhận xét: Có 21 trường hợp nạo vét hạch $\mathrm{N} 1(58,3 \%)$ và 25 trường hợp nạo vét hạch $\mathrm{N} 2$ $(69,4 \%)$ trong mổ, số hạch trung bình vét được trong một ca mổ là 1,6 $\pm 1,0$ hạch.

\subsection{Kết quả sớm}

Bảng 3.9. Thời gian, máu mất phẫu thuật

\begin{tabular}{|c|c|c|c|}
\hline Chỉ tiêu & PTNS hoàn toàn & PTNS hỗ trọ̆ & P values \\
\hline \multirow{2}{*}{ Thò̀i gian (phút) } & $149,0 \pm 33,2$ & $154,5 \pm 40,7$ & \multirow{2}{*}{$\mathbf{0 . 0 5}$} \\
\cline { 2 - 3 } & \multicolumn{2}{|c|}{$\mathbf{1 5 0 , 9 \pm \mathbf { 3 5 , 5 }}$} & \\
\hline \multirow{2}{*}{ Máu mất (ml) } & $94 \pm 60,2$ & $100 \pm 59,3$ & \\
\cline { 2 - 3 } & \multicolumn{2}{|r|}{$\mathbf{9 6} \pm \mathbf{4 8 , 3}$}
\end{tabular}

Nhận xét: Sự khác biệt về thời gian và máu mất theo phương pháp PTNS không có ý nghĩa thống kê $(\mathrm{p}>0,05)$.

Bảng 3.10. Tai biến, biến chứng

\begin{tabular}{|l|c|c|}
\hline \multicolumn{1}{|c|}{ Tai biến, biến chứng } & Số bệnh nhân & Tỷ lệ (\%) \\
\hline Tổn thương mạch máu & 2 & 6,4 \\
\hline Rò khí kéo dài sau mổ & 2 & 6,4 \\
\hline Tử vong & 0 & 0,0
\end{tabular}

Nhận xét : 2 trường hợp có tai biến chảy máu trong mổ: 01 do rách ĐM phổi khi cắt thùy trên phổi $(\mathrm{P}) ; 01$ do rách TM phổi ở bệnh nhân được cắt thùy trên $(\mathrm{T})$

Bảng 3.11. Thời gian dẫn lưu khoang màng phổi và nằm viện sau mổ

\begin{tabular}{|l|c|c|c|}
\hline \multicolumn{1}{|c|}{ Chỉ tiêu } & Ngắn nhất & Dài nhất & Trung bình \\
\hline Thời gian dẫn lưu KMP (ngày) & 3 & $\mathbf{1 0}$ & $4,0 \pm 1,9$ \\
\hline Thời gian nằm viện sau mổ (ngày) & 6 & 16 & $9,8 \pm 3,3$ \\
\hline
\end{tabular}




\section{BÀN LUẬN}

\subsection{Về đặc điểm chung}

- Phân bố về giới: Tỷ lệ bệnh nhân theo giới có sự khác nhau trong các nghiên cứu. Mc Kenna [3] thực hiện PTNS cho 1100 bệnh nhân, tỷ lệ nam, nữ lần lượt là $45,9 \%$ và $54,1 \%$. Trong nghiên cứu của chúng tôi, tỷ lệ nam, nữ lần lượt là $80,6 \%$ và $19,4 \%$.

- Phân bố về tuổi: Cắt thùy phổi bằng PTNS có thể thực hiện được ở các bệnh nhân lớn tuổi (BN lớn tuổi nhất trong nghiên cứu là 72 tuổi) nếu chức năng tim, phổi cho phép. Chỉ định này phù hợp với quan điểm của các tác giả khác [3-5].

\section{2. Đặc điểm kỹ thuật}

\subsubsection{Chỉ định PTNS cắt thùy phổi}

- Vị trí thùy phổi được cắt: PTNS có thể được áp dụng để cắt tất cả các thùy phổi, tuy mức độ khó khăn khi thực hiện phẫu thuật là khác nhau. Các tác giả như Yim P. C [6], Gossot. D [7] đều cho rằng PTNS cắt thùy trên phổi, đặc biệt thùy trên phổi trái có độ khó cao nhất. Chúng tôii, đã thực hiện cắt các thùy phổi có u ở tất cả các vị trí (bảng 3.1) trong giai đoạn đầu ứng dụng kỹ thuật PTNS, mặc dù số lượng bệnh nhân còn hạn chế nhưng với quá trình chuẩn bị chu đáo trên mô hình thực nghiệm, phẫu thuật viên là những người đều có bề dày kinh nghiệm trong phẫu thuật phổi mở. Do vậy, đảm bảo an toàn, khả thi.

- Kích thước khối u: trung bình là 3,3 31,4 $\mathrm{cm}$, u lớn nhất là $7,5 \mathrm{~cm}$, phù hợp với chỉ định phẫu thuật nội soi cắt thùy phổi.

- Bệnh lý phổi: PTNS là cách tiếp cận mới trong điều trị phẫu thuật các bệnh lý phồi. Chỉ định cắt thùy phổi trong điều trị phụ thuộc vào từng bệnh lý cụ thể. Áp dụng PTNS trong cắt thùy phổi để điều trị các bệnh lý phổi của chúng tôi là tương tự các tác giả khác [1], [4].

- Giai đoạn TNM: Theo McKennna R. J. và cs (2006), có thể chỉ định PTNS điều trị cho những bệnh nhân UTP không TBN giai đoạn đến IIIA. Trong số 1015 trường hợp được phẫu thuật, giai đoạn I chiếm 87,9\%, IIA tỷ lệ 1,3\%, IIB tỷ lệ $0,9 \%$ và IIIA tỷ lệ $2,2 \%$ [1]. Tuy vậy, nhìn chung các báo cáo cho thấy, PTNS điều trị UTP không TBN được chỉ định giới hạn ở những bệnh nhân giai đoạn sớm I đến II [2], [1], [13]. Chúng tôi, thực hiện cắt thùy phổi ở những bệnh nhân UTP không TBN giai đoạn I và II chiếm chủ yếu, tỷ lệ $92,2 \%$.

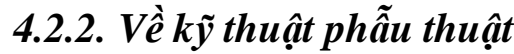

- Đường vào

Các nghiên cứu cho thấy có sự khác nhau về số lượng trocar sử dụng trong mổ, có thể từ 1 đến 4 . Chúng tôi luôn đặt 02 trocar ở tất cả các trường hợp: 01 trocar cho ống soi, trocar còn lại là cửa cho dụng cụ kéo, vén phổi. Quá trình phẫu thuật thuận lợi, không cần đặt thêm trocar khác.

Mở ngực nhỏ luôn được chúng tôi thực hiện từ đầu, ngay sau khi đưa ống soi vào KMP quan sát đánh giá tổn thương. Khi khối u phổi có kích thước lớn (trên $5 \mathrm{~cm}$ ) hay rãnh liên thùy không hoàn toàn, thường đường mở ngực dài hơn và chúng tôi thực hiện PTNS hỗ trợ. Đường mở ngực cũng luôn ở trước đường nách trước vì ở vị trí này KLS rộng hơn, dễ dàng hơn khi banh rộng vết mổ khi cần thiết (sử dụng dụng cụ mổ mở cán dài, lấy thùy phổi đã cắt ...) đồng thời vị trí này cho phép kiểm soát ĐM phổi tốt hơn, dễ và nhanh hơn trong xử trí tai biến chảy máu ...

- Phương pháp PTNS lồng ngực: Mặc dù còn nhiều vấn đề còn đang được tiếp tục tranh cãi về khái niệm PTNS lồng ngực cắt thùy phổi, trên thực tế, các nghiên cứu về ứng dụng PTNS cho thấy hai phương pháp thể hiện cấp độ khác nhau trong khai thác ưu thế của PTNS (phóng đại hình ảnh, quan sát được ở những góc khuất mà nếu nhìn trực tiếp rất khó khăn ...) vẫn đang được ứng dụng song hành: PTNS hoàn toàn và hỗ trợ. Nhìn chung, PTNS hoàn toàn có độ khó cao hơn, đòi hỏi dụng cụ PTNS chuyên dụng, chỉ định hẹp hơn ... Có thể nói PTNS như là một kỹ thuật trung gian của PTNS hoàn toàn và mổ mở.

Tại Bệnh viện 103, cả hai phương pháp PTNS đã và đang được áp dụng. Với tỷ lệ áp dụng lần lượt là $64,6 \%$ và $35,4 \%$. Phân tích chúng tôi thấy, PTNS hỗ trợ thường được áp dụng ở những trường hợp có $\mathrm{u}$ phổi to từ $5 \mathrm{~cm}$ trở lên, rãnh liên thùy không hoàn toàn (bảng 3.6). Như vậy sẽ giúp quá trình bộc lộ, phẫu tích thuận lợi hơn, an toàn hơn. 
- Thứ tự cắt mạch máu cuống thuỳ: Không có quy tắc chung về thứ tự cắt các mạch máu cuống thùy phổi. Thực tế chúng ta thấy: các mạch ở sâu, bị che bới nhánh mạch khác chỉ được phẫu tích, cắt khi đã khâu, cắt các nhánh mạch gây cản trở. Khi $\mathrm{TM}$ và $\mathrm{ĐM}$ của thùy phổi xa nhau, thứ tự ưu tiên xử lý là $Đ M$ rồi đến $T M$, vì như vậy sẽ không làm tăng áp lực trong động mạch phổi và phế quản, giảm nguy cơ chảy máu khi phẫu tích. Chúng tôi khi cắt thùy trên thường tiếp cận theo hướng từ trước, do vậy thường tiến hành phẫu tích và cắt $\mathrm{TM}$ phổi trên trước tiên để giúp phẫu tích, bộc lộ nhánh ĐM trung thất dễ dàng (14/14 trường hợp). TBN

- Vét hạch trong PTNS điều trị UTP không

Kể từ khi bản đồ hạch được giới thiệu bởi Naruke vào năm 1978, phẫu thuật lấy hạch trung thất và trong rốn phổi và trong phổi có vai trò quan trọng trong sự phân chia giai đoạn UTP sau phẫu thuật. Vét hạch là một kỹ thuật khó, ngay cả khi áp dụng mổ mở. Đã có nhiều tác giả tỏ ra lo lắng khi áp dụng PTNS trong điều trị UTP, bởi lo ngại sự hạn chế của kỹ thuật này về khả năng vét hạch. Tuy vậy, nhiều tác giả mà tiêu biểu là Scott W.J. và cs đã minh chứng khả năng vét hạch bằng PTNS tương đương mổ mở. Như vậy, vấn đề nằm ở kỹ năng phẫu thuật. Chúng tôi cho rằng vét hạch trong PTNS là khả thi vì :

+ Đa phần bệnh nhân ở giai đoạn sớm, hạch nhỏ, chưa xâm lấn nên việc phẫu tích, vét hạch thuận lợi

- Kết quả bước đầu của chúng tôi đã cho thấy PTNS có thể vét hạch tương đối hiệu quả với 21 trường hợp được vét hạch $\mathrm{N} 1(58,3 \%)$ và 25 trường hợp nạo vét hạch N2 $(69,4 \%)$ trong mổ, số hạch trung bình vét được trong một ca mổ là 1,6 $\pm 1,0$ hạch; trong đó có 4 trường hợp (chiếm tỷ lệ $12,5 \%$ ) có tế bào ung thư di căn hạch N1, 6 trường hợp (chiếm tỷ lệ 18,8\%) có tế bào ung thư di căn hạch N2.

\subsection{Về kết quả sớm}

- Thời gian phẫu thuật: thời gian phẫu thuật trung bình của chúng tôi đối với nội soi hỗ trợ và nội soi hoàn toàn lần lượt là $154,5 \pm 40,7$ phút và
149,0 \pm 33,2 phút. Kết quả tương tự các tác giả: Swanson S.J (130 phút) [2], Tomaszek S.C (139 phút) [8], Loscertales J (148 phút) [9].

- Tai biến trong mổ: 02 trường hợp trong quá trình phẫu thuật có tổn thương mạch máu thùy phổi (01 trường hợp tổn thương động mạch và 01 trường hợp tổn thương tĩnh mạch), đã được chuyển mổ nội soi hỗ trợ để an toàn cho bệnh nhân $(6,4 \%)$. Tỉ lệ này thấp hơn so với Amer $\mathrm{K}$ $(14,7 \%)$ [10], nhưng cao hơn so với Mc Kenna R.J (2,5\%) [4] và Van Schil P. E (1,6\%) [11].

- Biến chứng sau mổ: Tỷ lệ biến chứng sau phẫu thuật trong nghiên cứu chúng tôi là $6,4 \%$ (02 trường hợp rò khí kéo dài). Kết quả này tương đương khi so sánh với các tác giả như: Loscetales J (12,8\%) [9], Solaini L (11,6\%) [12].

Không có trường hợp nào tử vong trong mổ và trong thời kỳ hậu phẫu. Sandra. $\mathrm{C}$ Tomaszek [8] phẫu thuật 56 bệnh nhân không có trường hợp nào tử vong trong mổ. Yamamoto. $\mathrm{K}$ [13] phẫu thuật cho 502 bệnh nhân ghi nhận tử vong sau mổ là $0,3 \%$. Mc Kenna [3] không có tử vong trong mổ, tỷ lệ tràn khí màng phổi là $5 \%$. Số lượng phẫu thuật của chúng tôi còn nhỏ nhưng kết quả là đáng khích lệ.

- Thời gian dẫn lưu KMP: thời gian dẫn lưu khoang màng phổi trung bình của các bệnh nhân trong nghiên cứu của chúng tôi là $6,1 \pm 0,7$ ngày; ngắn nhất là 3 ngày, dài nhất là 10 ngày do có biến chứng rò khí kéo dài sau mổ. Theo Tomaszek [8], ống dẫn lưu được rút sau trung bình 2 ngày (1 - 12 ngày).

- Thời gian nằm viện sau mổ: của chúng tôi trung bình là $9,8 \pm 3,3$ ngày. So với một số tác giả thì thời gian hậu phẫu của chúng tôi dài hơn như Yamamoto K (6,5 ngày) [14], Swanson S.J (6,15 ngày) [2].

\section{Kết luận}

Bệnh viện Quân y 103 bước đầu đã áp dụng PTNS cắt thùy phổi điều trị các bệnh lý phổi hiệu quả, tỷ lệ áp dụng PTNS hoàn toàn cao $(64,6 \%)$, kết quả khả quan với tai biến và biến chứng thấp $(6,4 \%)$, không có tử vong trong mổ và trong thời gian hậu phẫu. 


\section{TÀI LIẸU THAM KHẢO}

1. P. Modi, et al. (2009), "Minimally invasive video-assisted mitral valve surgery: a 12-year, 2-center experience in 1178 patients", $J$ Thorac Cardiovasc Surg. 137(6), pp. 1481-7.

2. S. J. Swanson, et al. (2007), "Videoassisted thoracic surgery lobectomy: report of CALGB 39802--a prospective, multi-institution feasibility study", J Clin Oncol. 25(31), pp. 4993-7.

3. R. J. McKenna, Jr., W. Houck, and C. B. Fuller (2006), "Video-assisted thoracic surgery lobectomy: experience with 1,100 cases", Ann Thorac Surg. 81(2), pp. 421-5; discussion 425-6.

4. P. E. Van Schil, et al. (2013), "Surgical treatment of early-stage non-small-cell lung cancer", EJC Suppl. 11(2), pp. 110-22.

5. D. Dziedzic and T. Orlowski (2015), "The Role of VATS in Lung Cancer Surgery: Current Status and Prospects for Development", Minim Invasive Surg. 2015, p. 938430.

6. Yim A. P. C., et al. (2000), Minimal Access Cardiothoracic Surgery, W. B. Saunders company, USA.

7. Gossot D. (2010), Atlas of Endoscopic Major Pulmonary Resections, Springer, Paris France.
8. S. C. Tomaszek, et al. (2009), "Clinical Outcomes of Video-Assisted Thoracoscopic Lobectomy", Mayo Clin Proc. 84(6), pp. 509-13.

9. J. Loscertales, et al. (2010), "Videoassisted thoracic surgery lobectomy: results in lung cancer", J Thorac Dis. 2(1), pp. 29-35.

10. Amer K, Khan A, and Vohra $\mathbf{H}$ (2011), "Video-assisted thoracic surgery of major pulmonary resections for lung cancer: the Southampton experience", Eur J Cardiothorac Surg. 39(2), pp. 173-179.

11. M. W. Onaitis, et al. (2006), "Thoracoscopic Lobectomy Is a Safe and Versatile Procedure: Experience With 500 Consecutive Patients", Ann Surg. 244(3), pp. 420-5.

12. L. Solaini, et al. (2001), "Videoassisted thoracic surgery major pulmonary resections. Present experience", Eur J Cardiothorac Surg. 20(3), pp. 437-42.

13. K. Yamamoto, et al. (2010), "Longterm survival after video-assisted thoracic surgery lobectomy for primary lung cancer", Ann Thorac Surg. 89(2), pp. 353-9.

14. W. Wang, et al. (2014), "Comparative study of systematic thoracoscopic lymphadenectomy and conventional thoracotomy in resectable non-small cell lung cancer", $J$ Thorac Dis. 6(1), pp. 45-51. 